Review

\title{
Emerging Roles of Matricellular Proteins in Systemic Sclerosis
}

\author{
Daniel Feng ${ }^{1,2}$ and Casimiro Gerarduzzi $1,2,3, *$ \\ 1 Département de Pharmacologie et Physiologie, Faculté de Médecine, Université de Montréal, \\ Montréal, QC H3T 1J4, Canada; daniel.feng@umontreal.ca \\ 2 Centre de recherche de l'Hôpital Maisonneuve-Rosemont, Faculté de Médecine, Centre affilié à l'Université \\ de Montréal, Montréal, QC H1T 2M4, Canada \\ 3 Département de Médecine, Faculté de Médecine, Université de Montréal, Montréal, QC H3T 1J4, Canada \\ * Correspondence: casimiro.gerarduzzi@umontreal.ca; Tel.: +1-514-252-3400 (ext. 2813)
}

Received: 31 May 2020; Accepted: 13 June 2020; Published: 6 July 2020

check for updates

\begin{abstract}
Systemic sclerosis is a rare chronic heterogenous disease that involves inflammation and vasculopathy, and converges in end-stage development of multisystem tissue fibrosis. The loss of tight spatial distribution and temporal expression of proteins in the extracellular matrix (ECM) leads to progressive organ stiffening, which is a hallmark of fibrotic disease. A group of nonstructural matrix proteins, known as matricellular proteins (MCPs) are implicated in dysregulated processes that drive fibrosis such as ECM remodeling and various cellular behaviors. Accordingly, MCPs have been described in the context of fibrosis in sclerosis (SSc) as predictive disease biomarkers and regulators of ECM synthesis, with promising therapeutic potential. In this present review, an informative summary of major MCPs is presented highlighting their clear correlations to SSc- fibrosis.
\end{abstract}

Keywords: systemic sclerosis; fibrosis; extracellular matrix; matricellular proteins; myofibroblasts; biomarkers/therapeutics

\section{Introduction}

Systemic sclerosis (SSc) is a rare idiopathic disease that presents as a trifecta of compounding chronic abnormalities driven by autoimmunity, vasculopathy, and systemic tissue fibrosis [1]. SSc carries considerable phenotypic heterogeneity, which consequently leads to the poorly understood complex interplay amongst the dysregulated systems. As it affects major internal organ systems, such as the lungs and heart during disease progression, the fibrotic tissue decreases survival probability, and accounts for a large proportion of SSc-related deaths due to organ failure [2]. Optimistically, reports of survival rates amongst various global SSc cohorts published within the last 5 years have shown a steady upwards trend to $>90 \%$ and $80-90 \%$ in 5- and 10- year survival rates, respectively [3-7]. Innovations in earlier detection and improved stratification of SSc subtypes through advances in genomic and metabolic screening have led to consistent improvements, and has enabled healthcare professionals to make informed and timely decisions on appropriate therapeutic interventions [8-11].

The burden of organ fibrosis in SSc is the driving motivation behind a large number of novel research studies, with nearly double the amount of studies published on NCBI PubMed within the last decade (2470 publications listed under the key search terms of "systemic sclerosis" + "fibrosis") compared to previous years (1484 publications). Fibrosis is a deregulated repair process defined by the progressive stiffening and scarring of tissue due to the excessive deposition of extracellular matrix (ECM) components, causing loss of native organ architecture and impairment of homeostatic function [12,13]. Fibrogenesis of visceral organs pose significant stress on patient quality of life. In fact, the destructive scarring of the lungs is the leading cause of mortality in both diffuse (dcSSc) and limited 
(lcSSc) cutaneous SSc patient populations [14-16]. Apparent histological and physiological similarities exist amongst different organs in end-stage fibrotic disease; thus, leveraging this fact allows fibrosis research to discover conserved pathological mechanisms regardless of etiology.

At the root of fibrotic disorders is a dysregulated ECM caused by aberrant accumulation of structural matrix proteins, primarily collagens types I, III, and IV, fibronectin, fibrin, and elastins [17,18]. Consensus in the literature points to activated fibroblasts, known as myofibroblasts, as the primary effector cell type responsible for the overproduction and management of the various ECM components leading to elevated mechanical stress, tension, and reduced plasticity of the ECM network [18]. Myofibroblasts are not normally found in healthy connective tissue but emerge in circumstances of acute insults, chronic inflammation, and repeated tissue injury [19]. Myofibroblasts are shown to be vastly heterogenous in lineage and arise from not only differentiation of the reparative resident fibroblasts, but also circulating progenitor cells such as fibrocytes and pericytes that collectively contribute to the stiffening of the matrix environment [19-21]. After an injury has been resolved, the natural mechanisms for clearing myofibroblasts include apoptosis, dedifferentiation, and senescence, which happen to be deregulated in chronic injuries due to the prosurvival signals and biomechanical cues; hence, supporting their persistent activation and hindering fibrosis resolution [19].

Several key signaling pathways allow myofibroblasts to destructively release excessive ECM proteins while simultaneously evading their depopulation. TGF $\beta$ is a pleiotropic cytokine with broad downstream signaling effects that have been extensively reviewed in SSc pathogenesis for its roles in autoimmunity, vasculopathy, myofibroblast differentiation, and ECM synthesis $[19,20,22,23]$. The TGF $\beta$-induced phosphorylation of SMAD proteins (SMAD1 and SMAD2/3) underlies pathological fibrosis by stimulating both fibroblast to myofibroblast differentiation and activation of profibrotic genes, largely through $\alpha$-smooth muscle actin ( $\alpha \mathrm{SMA})$ and collagen upregulation, respectively [24-26]. Moreover, canonical Wnt-signaling in myofibroblasts via its ligands Wnt1, Wnt-3a, and Wnt-10b have been shown to upregulate expression of ECM encoding genes under ECM restructuring conditions $[20,27,28]$. Collectively, these pathways along with many others described in the literature empower myofibroblasts to be the driving force in fibrotic pathologies.

In addition to the aberrant biochemical signaling from myofibroblasts, the delicate balance in biomechanical forces of the ECM is disrupted. The ECM is increasingly being appreciated for its effect on cells during the processing of its structure to meet organ-specific demands. In recent years, we have been learning that one way by which this is achieved is through matricellular proteins (MCPs), which are a group of matrix proteins with nonstructural function and expressed in a context-dependent manner [29]. MCPs have also been emerging for their profound effects on myofibroblasts, such as their differentiation, recruitment, collagen synthesis, and apoptotic evasion under fibrotic conditions $[19,20,30,31]$.

\section{Function of MCPs}

In contrast to the classical structural proteins of the ECM, MCPs function distinctly as nonstructural extracellular signaling molecules that mediate the dynamic biochemical and biomechanical status of the ECM to the surrounding cell populations. Basal expression levels of MCPs are typically quite low after development, but are transiently re-expressed for their multitude of functions during early tissue remodeling processes. One context in which the role of MCPs is best exemplified is during wound repair, whereby tight temporal and spatial re-expression of MCPs are required for timely resolution of an injury. It may do so by contributing to the transformation of fibroblasts into myofibroblasts, and triggering intracellular events to stimulate proliferation, cell migration, and invasion of myofibroblasts to the injury site. Furthermore, their expression is associated with ECM remodeling processes such as stimulating synthesis of matrix proteins (i.e. collagen, fibronectin, and elastins) and proteolytic degradation of the ECM to regain the structural integrity lost after tissue damage. MCPs can also directly interact with matrix components through their distinct functional domains, allowing them to anchor to the ECM network [31]. These evolutionary conserved functional domains have been used to 
classify and group like MCPs together into six unique families: Centralized Coordination Network $(\underline{\mathrm{CCN}})$, Thrombospondin (THBS), Secreted Protein Acidic and Rich in Cysteine (SPARC), Tenascin (TN), Small Integrin-Binding Ligand N-Linked Glycoprotein (SIBLING), and $\gamma$-carboxyglutamate (Gla)-containing proteins [32].

As extracellularly localized molecules, MCPs are capable of communicating with surrounding cells by engaging different cell surface receptors to elicit an intracellular response (Table 1). One of the most common interactions is the binding of MCPs with integrins, which are cell surface $\alpha \beta$ heterodimeric receptors. Integrins are composed from one of $18 \alpha$ subunits and $8 \beta$ subunits, which form unique combinations to recognize and bind different ECM molecules. Integrin-mediated signaling enables MCPs to physically bridge the ECM with the cellular cytoskeleton and relay dynamically changing ECM structures to the cell. This occurs through a process called mechanotransduction, whereby extracellular physical changes that alter the plasticity (i.e. stiffening, degradation) of the ECM can be transformed intracellularly to induce chemical signaling cascades $[33,34]$. In addition to integrins, MCPs can also bind to membrane-bound heparan sulfate containing proteoglycans such as syndecans, which can act independently or as coreceptors to integrins and growth factor receptors to modulate cell-matrix interactions $[35,36]$. For example, syndecan-MCP and syndecan-integrin interactions are important for focal adhesion formation during cell adhesion and spreading, as well as the activation of focal adhesion kinases to induce actin reorganization [37]. MCP binding to cell surface calreticulin is also known to mediate assembly and disassembly of focal adhesions by activation of signaling pathways such as PI3K and ERK [38]. The presence of divalent ions (i.e. $\mathrm{Ca}^{2+}$ and $\mathrm{Zn}^{2+}$ ) as well as binding of coreceptors, such as LDL-receptor-related proteins, can additionally enhance calreticulin-MCP functions. Recognition of cell membrane receptors CD36, CD44, and CD47, predominately by thrombospondins, in contexts of cell senescence, cancer, and immune regulation further emphasize the breadth of MCP receptor binding partners [39-41]. Other unique interactions of MCPs include tyrosine kinase receptor TrkA, Wnt-receptors LRP1 and LRP6, Annexin II, EGFR, and TLR4 (Table 1) [36,42-44].

Table 1. Summary of major matricellular proteins (MCPs) in systemic sclerosis (SSc) fibrosis

\begin{tabular}{|c|c|c|c|}
\hline MCP Family & $\begin{array}{l}\text { MCP Family Members } \\
\text { Upregulated in SSc }\end{array}$ & Bound Receptors & General Fibrotic Roles in SSc \\
\hline \multirow{3}{*}{$\mathrm{CCN}[36,42,45,46]$} & CCN1 & $\begin{array}{c}\text { Integrin }\left(\alpha_{2} \beta_{1}, \alpha_{6} \beta_{1}, \alpha \operatorname{Ilb} \beta_{3}, \alpha \mathrm{D} \beta_{2},\right. \\
\left.\alpha \mathrm{M} \beta_{2}, \alpha \mathrm{v} \beta_{1}, \alpha \mathrm{v} \beta_{3}, \alpha \mathrm{v} \beta_{5}\right) \\
\text { syndecan-4 }\end{array}$ & $\begin{array}{l}\text { - Both pro- and antifibrotic roles } \\
\text { - CCN1 KO in mice limited type } \\
\text { I collagen } \\
\text { - Overexpression of CCN1 in SSc dermal } \\
\text { fibroblasts downregulates } \\
\text { COL1A1 expression }\end{array}$ \\
\hline & CCN2 & $\begin{array}{c}\text { Integrins }\left(\alpha_{4} \beta_{1}, \alpha_{5} \beta_{1}, \alpha_{6} \beta_{1}, \alpha \mathrm{M} \beta_{2}\right. \\
\left.\alpha \mathrm{v} \beta_{1}, \alpha \mathrm{v} \beta_{3}\right), \mathrm{LRP} 1, \mathrm{LRP} 6 \\
\text { syndecan- } 4, \text { TrkA }\end{array}$ & $\begin{array}{l}\text { - Expression induced by TGF } \beta \text {-SMAD } \\
\text { signaling and } \\
\text { mechanotransduction mechanisms } \\
\text { - Induces } \alpha \text { SMA expression in SSc } \\
\text { lung fibroblasts }\end{array}$ \\
\hline & CCN3 & Integrins $\left(\alpha_{5} \beta_{1}, \alpha_{6} \beta_{1}, \alpha v \beta_{1}, \alpha v \beta_{5}\right)$ & $\begin{array}{c}\text { - Overexpression in Tsk1/+ mice } \\
\text { downregulates fibrillin-1 and TGF } \beta / \text { Wnt } \\
\text { profibrotic genes }\end{array}$ \\
\hline \multirow{4}{*}{ THBS $[36,47-51]$} & THBS-1 & $\begin{array}{c}\text { Integrins }\left(\alpha v \beta_{3}, \alpha \operatorname{IIb} \beta_{3}, \alpha_{9} \beta_{1}, \alpha_{6} \beta_{1},\right. \\
\left.\alpha_{5} \beta_{1}, \alpha_{4} \beta_{1}, \alpha_{3} \beta_{1}, \alpha_{3} \beta_{1}\right), C D 36, C D 47 \\
\text { CD148, LRP1, syndecan-3 and } \\
-4, \text { calreticulin }\end{array}$ & $\begin{array}{l}\text { - Endogenous activator of latent TGF } \beta \\
\text { Enhances contractile activity of SSc } \\
\text { fibroblasts by activation of } \\
\text { MEK/ERK pathway }\end{array}$ \\
\hline & THBS-2 & $\begin{array}{l}\text { Integrins }\left(\alpha v \beta_{3}, \alpha \operatorname{IIb} \beta_{3}, \alpha_{9} \beta_{1}, \alpha_{6} \beta_{1}\right. \\
\left.\alpha_{4} \beta_{1}\right), \mathrm{CD} 36, \mathrm{CD} 47, \mathrm{LRP} 1, \text { syndecan-4 }\end{array}$ & $\begin{array}{l}\bullet \text { Silencing in SSc fibroblasts } \\
\text { downregulates type I collagen synthesis }\end{array}$ \\
\hline & THBS-4 & Integrins $\left(\beta_{1} D, \beta_{2}, \beta_{3}\right)$ & $\begin{array}{l}\text { - Supports collagen deposition (I, II, III, } \\
\text { V) and displays proangiogenic effects } \\
\text { through TGF } \beta \text {-SMAD3 signaling }\end{array}$ \\
\hline & THBS-5 & Integrins $\left(\alpha_{5} \beta_{1}, \alpha v \beta_{3}\right)$ & $\begin{array}{l}\text { - Promotes aberrant secretion of collagen } \\
\text { and fibronectin leading to matrix stiffening }\end{array}$ \\
\hline
\end{tabular}


Table 1. Cont.

\begin{tabular}{|c|c|c|c|}
\hline MCP Family & $\begin{array}{l}\text { MCP Family Members } \\
\text { Upregulated in SSc }\end{array}$ & Bound Receptors & General Fibrotic Roles in SSc \\
\hline \multirow{2}{*}{ SPARC [52-54] } & SPARC & $\begin{array}{l}\text { Integrin } \alpha_{5} \beta_{1} \text {,TGF- } \beta \\
\text { receptor, endoglin }\end{array}$ & $\begin{array}{l}\text { - Inhibition in SSc dermal fibroblasts } \\
\text { downregulates type I collagen and CCN2 } \\
\text { - Blocking TGF } \beta \text {-SMAD2 signaling limits } \\
\text { profibrotic functions of SPARC in vitro }\end{array}$ \\
\hline & FSTL1 & Integrin $\beta 3$ & $\begin{array}{l}\text { - Limited reports on fibrotic roles but } \\
\text { evidence supports a proangiogenic role } \\
\text { in SSc dermal endothelial cells }\end{array}$ \\
\hline $\operatorname{TN}[36,43,44]$ & TN-C & $\begin{array}{c}\text { Integrins }\left(\alpha_{2} \beta_{1}, \alpha_{5} \beta_{1}, \alpha 7 \beta_{1}, \alpha_{8} \beta_{1}\right. \\
\left.\alpha_{9} \beta_{1}, \alpha v \beta_{3}, \alpha v \beta_{6}, \alpha v \beta_{1}\right), \text { Syndecan- } 4, \\
\text { Annexin II, EGFR, TLR4 }\end{array}$ & $\begin{array}{l}\text { - Mediates both profibrotic and } \\
\text { inflammatory signaling by } \\
\text { TLR4-dependent mechanism } \\
\text { - KO mice limits infiltration of } \\
\text { myofibroblasts, macrophages, } \\
\text { and lymphocytes in pulmonary fibrosis }\end{array}$ \\
\hline SIBLING $[36,55]$ & OPN & $\begin{array}{l}\text { Integrins }(\alpha \mathrm{v} \beta 1, \alpha \mathrm{v} \beta 3, \alpha \mathrm{v} \beta 5, \alpha \mathrm{v} \beta 6, \\
\alpha 5 \beta 1, \alpha 8 \beta 1, \alpha 9 \beta 1, \alpha 4 \beta 7 \text {, and } \alpha 4 \beta 1) \\
\text { and CD44 }\end{array}$ & $\begin{array}{l}\text { - Regulates deposition of type I and } \\
\text { IV collagen, } \\
\text { - Regulates local TGF } \beta \text { activity } \\
\text { - Stimulates myofibroblast proliferation }\end{array}$ \\
\hline \multirow[t]{2}{*}{ Gla-Family [56] } & POSTN & Integrins $\left(\alpha v \beta 3, \alpha v \beta_{5}\right)$ & $\begin{array}{l}\text { - Colocalizes with } \alpha \text { SMA-positive } \\
\text { expressing cells in lesional skin } \\
\text { - Induces fibroblast differentiation } \\
\quad \text { to myofibroblasts } \\
\text { - Promotes collagen deposition }\end{array}$ \\
\hline & MGP & Unknown & $\begin{array}{l}\text { - No direct studies linking MGP to } \\
\text { fibrosis in SSc but may be implicated with } \\
\text { calcinosis with SPARC }\end{array}$ \\
\hline
\end{tabular}

Intracellular signal transduction is also mediated by MCPs through modulation of soluble matrix cytokines and growth factors. Importantly, their interaction with pleiotropic signaling molecules such as TGF $\beta$, VEGF, Wnt, and EGF confer broad biological functions such as stimulating ECM production and remodeling, angiogenesis, and regulating cellular differentiation [36]. To regulate these functions, MCPs can affect conformational changes in the ECM to release embedded growth factors and convert latent forms of biomolecules in the ECM [36].

Owing to their dysregulation of diverse functions in human pathology, MCPs have certainly not been ignored in disease but perhaps their potential has not been entirely realized either. MCPs are largely recognized in fibrotic settings where excessive ECM production is central to disease progression. As fibrosis is one of the central axes of disease in SSc, this review aims to bring attention to the current insights of MCPs in SSc by discussing the burgeoning roles of the most well-known MCP families.

\section{CCN Family}

The CCN family of MCPs are composed of six proteins designated CCN1 to CCN6. Of greatest structural significance to this family of proteins is their unique tetramodular organization that confer vast biological properties acting both independently and/or complementary to one another [57]. Loss of tight spatial-temporal regulation of $\mathrm{CCN}$ proteins in wound healing triggers a maladaptive repair program affecting processes of inflammation, proliferation, and tissue remodeling that can lead to development of fibrosis-related pathologies such as SSc [58-60]. Amongst the CCN family, CCN1 and CCN2 make up the majority of MCPs studied in SSc research while CCN3-6 are less understood but have emerging functions.

CCN1 (alternatively cysteine-rich angiogenic protein 61, CYR61) is a well characterized MCP with generally profibrotic and angiogenic influence [61]. Post developmental expression of CCN1, like many MCPs is observed during tissue damage and disease; however, circulating levels of CCN1 in serum samples of SSc patients have been inconsistently reported in the literature. Lin et al. report CCN1 to be significantly elevated in SSc from their analysis of several autoimmune diseases [62], while other reports found no difference in plasma CCN1 in both lcSSc and dcSSc patients versus healthy controls [63,64]. Protein levels of CCN1 from dermal fibroblasts of lesioned skin also reveal conflicting expression patterns. Comparable expression between healthy and SSc-derived fibroblasts was reported 
by Tsou et al., while fibroblasts from a small cohort of patients with early onset ( $<2$ years) dcSSc found CCN1 to be overexpressed in comparison to healthy matched controls [63,65].

CCN1 has also been conflicting for its mechanistic role in SSc, showing both pro- and antifibrotic effects. Using an in vivo model of bleomycin-induced skin scleroderma in mice, targeted knockout of $\mathrm{CCN} 1$ in fibroblasts limited type 1 collagen accumulation with reduced skin thickness [65]. Alternatively, CCN1 overexpression in isolated dermal fibroblasts cultured from skin biopsies of dcSSc patients suggest an antifibrotic role due to the downregulated expression of fibrotic genes COL1A1 and ACTA2, and consequently, slower cell migration and diminished gel contractile strength [63]. A mechanistic explanation by Tsou et al. propose a twofold rationale for the attenuation of fibrogenesis by CCN1 overexpression in these dcSSc fibroblasts. They describe an impairment of TGF $\beta$ receptor-II and SMAD2/3 phosphorylation, which is further compounded by elevated levels of reactive oxygen species activating various senescent signaling cascades (p38 MAPK, p53, and p16/phospho-pRB) [63].

CCN2 (alternatively connective tissue growth factor, CTGF) is the most well-known CCN family member. Accumulated evidence has proved its essential role in mediating organ fibrosis of different etiologies [66,67]. In SSc, overexpression of CCN2 is a systemic phenomenon with elevated mRNA and protein levels detected not only in areas of lesioned fibrotic skin but also in the dermal interstitial fluid and serum of SSc patients [67-70]. CCN2 is also upregulated in the epidermal layer of SSc skin and in epidermis-conditioned media of SSc patients when compared to healthy controls [71]. Soluble CCN2 is also shown to concentrate at the epidermis-dermis junction and blood vessels, supporting the notion that it is a crucial factor in maintaining epidermal fibrosis in SSc. Mechanistically, CCN2 can be induced by TGF $\beta$ signaling in a SMAD-dependent fashion but is also upregulated in response to biomechanical changes in the ECM during tissue stiffening in fibrosis [72,73]. Contractility of SSc lung fibroblasts was found to be greater with the addition of recombinant $\mathrm{CCN} 2$ protein, which correlated with $\alpha \mathrm{SMA}$ expression [74]. Moreover, enhanced expression of CCN2 by scleroderma fibroblasts is shown to promote collagen gel contraction that is dependent on transcription factors known to communicate mechanical adaptions and cues from the ECM [75]. In a separate study, CCN2 was further shown to be upregulated in SSc fibroblasts stimulated with TGF $\beta$ and seeded on rigid polyacrylamide gels that recapitulated stiffness of sclerotic dermal tissue [76]. Overall, the mechanoregulatory roles of CCN2 is a growing topic of interest in scleroderma with various pieces of evidence supporting the notion that it is a crucial factor in maintaining epidermal fibrosis in SSc.

CCN3 (alternatively nephroblastoma overexpressed, Nov) is regarded as an antagonist to CCN2 in fibrosis [59]. Its antifibrotic effect has been suggested to work via repression of CCN2, possibly by non-SMAD-dependent signaling pathways or affecting gene expression of other $\mathrm{CCN}$ members like CCN4 $[59,77,78]$. Microarray analysis of both lcSSc and late dcSSc skin biopsies reveal no significant difference in CCN3 expression, while a modest upregulation is observed in early dcSSc skin [79]. In the tight-skin (Tsk1/+) mice model of SSc, overexpression of CCN3 was found to repress fibrillin-1 and elastin assembly by antagonistically modulating TGF $\beta$ and Wnt-regulated gene expression [79].

CCN4-6 are a set of three Wnt-pathway target genes; hence, they are alternatively abbreviated as WNT1-inducible-signaling pathway protein 1-3 (Wisp-1-3), respectively. Presently, little is known regarding this trio of CCN proteins in the context of SSc, but further studies could potentially discover an association since they are known for their roles in non-SSc-related fibrotic disorders $[80,81]$. From biopsies of SSc skin, CCN4 and CCN6 expression was not detected at the mRNA level, while CCN5 expression was reported to be downregulated when compared to normal patients $[60,82]$. In a different patient cohort, microarray data revealed CCN4 to be strongly associated with the profibrotic transcription factor Egr-1, which is also a downstream target of TGF $\beta$ in primary human fibroblasts $[79,83]$. CCN4 also promotes alveolar type II cell proliferation, matrix metalloprotease (MMP) secretion, and fibroblast matrix secretion in interstitial lung disease, each a common fibrotic manifestation in SSc $[84,85]$. Although CCN4-6 have not been directly studied for their mechanisms in SSc, it is very likely that their known interaction with Wnt signaling may be involved since the pathway is prominently altered in SSc. 


\section{Thrombospondin Family}

The thrombospondins are matrix-secreted glycoproteins that consist of five family members sharing a conserved signature domain (THBS-1-5) [86]. THBS proteins are organized in a modular fashion as trimeric (THBS-1,2) and pentameric (THBS-3-5) oligomer structures. THBS proteins interact with an array of matrix molecules to activate various pathways implicated in tissue repair, ECM remodeling and mineralization, and angiogenesis [87-89]. Research on THBS proteins in SSc suggest an overall profibrotic role for THBS-1,2,4, and -5, while THBS-3 has not yet been described.

THBS-1 is a widely recognized profibrotic MCP found to be overexpressed in fibrosis of various organs, such as in the kidneys and lungs [90]. In SSc, THBS-1 is a predictive longitudinal biomarker of lesioned skin development, as proposed originally by the Lafyatis group in their four-gene biomarker set for SSc $[8,91,92]$. Its emergence as a reliable marker of fibrotic progression has been leveraged as a comarker for monitoring disease development and response to therapeutics in SSc [92-95]. Several recent and on-going clinical trials also show THBS-1 to parallel changes in modified Rodnan skin scores (MRSS) from skin biopsies, which is considered the gold standard for assessing improvement in skin thickness in response to therapeutics [93-95]. In vitro experiments using dcSSc dermal fibroblasts by Chen et al. have also demonstrated that THBS-1 expression is induced by mechanical force loading, and is an endogenous activator of latent TGF $\beta$ during matrix contraction to enhance contractile activity of pathological SSc fibroblasts [96]. In the same study, expression of THBS-1 in SSc fibroblasts was also limited by inhibiting the PDGF pathway with pharmacologic agents that antagonized MEK/ERK pathway activation. Finally, a selective inhibitor of THBS-1 has been recently shown to serve as a novel hypertrophic scar treatment [97]. Upregulated THBS-1 in scarred skin was antagonized by a LSKL (leucine-serine-lysine-leucine) peptide that augmented fibroblast contractility and attenuated release of type I collagen and $\alpha$ SMA accumulation [97]. Taken together, inhibiting THBS- 1 may be effective in managing multiple symptoms of SSc at different stages of disease progression.

Pioneer work on MCPs by the Bornstein group established a role of THBS-2 as a crucial modulator of collagen fibrillogenesis in ECM assembly and wound repair, as well as influencing fibroblast adhesion and contraction [98,99]. In the case of SSc patients, THBS-2 is elevated in skin biopsy sections and the serum of those containing pitting scars and/or ulcers, when compared to healthy controls [100]. In vitro analysis of isolated SSc dermal fibroblasts found THBS-2 mRNA to be downregulated, but a significant extracellular accumulation of THBS-2 was observed in the culture medium and immunohistological staining of biopsy sections. Moreover, silencing of THBS-2 by siRNA downregulated type I collagen synthesis in SSc fibroblasts. Taken together, the extracellular presence of THBS-2 contributes to the upregulation and buildup of type I collagen, which could then promote a profibrotic environment in scleroderma.

THBS-5, or alternatively cartilage oligomeric matrix protein (COMP), is constitutively expressed in the ECM of connective tissues and functions as a catalyst for collagen fibrillogenesis [101,102]. THBS-5 has emerged as a key component of homeostatic matrix remodeling through its interaction with structural proteins in the ECM (collagen, fibronectin, and matrilin), growth factors (TGF $\beta$ and BMP-2,4,7), and proteases (MMP-13 and ADAMTS-4,7,12) via distinct portions of its conserved signature domain [103-105]. In correlation to these profibrotic factors, THBS-5 overexpression was observed and involved in various fibroproliferative pathologies. THBS- 5 was also a part of the Lafyatis SSc four-gene biomarker set, and detection of serum THBS- 5 in early diagnosed SSc patients has been shown to be predictive of pulmonary fibrosis onset and mortality [92,106]. Moreover, serum THBS-5 was shown to parallel progressive changes in total skin thickness as measured using standardized methods such as MRSS and high frequency ultrasound [107]. Accumulation of THBS- 5 in the dermis is spatially heterogenous and largely secreted by SSc fibroblasts in response to autocrine TGF $\beta$ stimulation, which leads to matrix stiffening and skin tightening by excessive collagen deposition [108].

Although very little is known regarding THBS-4 in SSc, its fibrotic properties are largely described in the context of cardiac tissue remodeling where mice lacking THBS-4 develop interstitial fibrosis by inducing increased deposition of collagen I, II, III, and V [109]. Recent reports also suggest that 
the upregulation of THBS-4 expression by TGF $\beta$ is mediated specifically by SMAD3 signaling to exert proangiogenic effects [110]. Therefore, understanding THBS-4 in other fibrotic pathologies could help to better understand its role in SSc. Interestingly, the only documented case of THBS-4 in SSc was recently published by Moon et al. The group applied a method of machine learning to mine a gene expression compendium of SSc patients and identified the genes THBS-1, THBS-4, THBS-5, FN1, and $T N-C$ to best represent changes in the severity of skin fibrosis [111]. This representative gene set displayed the strongest correlation to MRSS fibrotic scores, which was likely due to their ability to drive skin fibrosis.

Members of the THBS family are well documented for their role in different organ fibrotic mechanisms, though those implicated in driving the pathology of SSc are less understood. While having clinical relevance as serological biomarkers for the fibrotic burden in SSc, THBS proteins, particularly THBS-3, present an area of opportunistic research to better understand their contributing roles in SSc fibrosis, which can be potentially aided by drawing parallels with their roles in other fibrotic organ models.

\section{SPARC Family}

The SPARC family is made up of the eight proteins, SPARC, SPARCL1, SMOC-1-2, SPOCK-1-3, and FSTL1, all of which share a follistatin-like domain and an extracellular calcium-binding domain [112]. SPARC family members are broad functioning matrix modulating proteins expressed in connective tissues and have been associated with a large spectrum of human pathologies, from maladaptive tissue repair to cancer and autoimmune disorders [52,112-114]. In SSc, particular attention has been given to SPARC and FSTL1, while the other family members are very understudied.

SPARC is among one of the first MCPs described and has since been an invaluable template in dissecting the role of MCPs in disease. SPARC overexpression is a common theme in various fibrotic pathologies, including SSc where elevated circulating SPARC is observed in SSc patients compared to matched counterparts $[115,116]$. At the cellular level, RT-PCR analysis of fibroblasts isolated from lesioned skin of dcSSc patients show an upregulation of fibrotic ECM genes COL1A2 and COL3A1, as well as fibrotic MCP genes SPARC and CCN2 when compared to healthy controls [117]. Silencing SPARC expression in such fibroblasts by siRNA was sufficient to reduce type I collagen and CCN2 expression. Conversely, SSc dermal fibroblasts treated with exogenous SPARC protein induced protein expression of collagen I, IV, fibronectin, and TGF $\beta$ in a dose-dependent manner [118]. Antagonizing TGF $\beta$ signaling in these fibroblasts with a TGF $\beta-R 1$ inhibitor (galunisertib) blocked phosphorylation of SMAD2, which consequently inhibited the effects of SPARC stimulation. Lastly, an epigenetic relationship has also been reported in Choctaw Native Americans in which several SPARC single nucleotide polymorphisms have been associated with a higher prevalence of SSc in this population [119].

FSTL1 has been studied in fewer SSc cases in comparison to SPARC. One particular study has detected elevated levels of circulating FSTL1 in the sera of SSc patients [120]. From a study of epigenetic mechanisms regulated by histone deacetylases (HDAC), FSTL1, CCN1, and PVRL2 have been reported for its angiogenic and fibrotic function on dermal endothelial cells (EC) from dcSSc patients [121]. Dual inhibition of HDAC5 in conjunction with either FSTL1, CCN1 or PVRL2 inhibited angiogenesis, while their overexpression led to an increase in EC tube formation. Despite the limited literature, FSTL1 has promising expectations in SSc when considering the evidence of its involvement in several conventional mechanisms of fibrosis [122-124].

\section{Tenascin Family}

The tenascin family is composed of four members, Tenascin-C, $-\mathrm{X},-\mathrm{R}$, and $-\mathrm{W}$ (TN-C, TN-X, $\mathrm{TN}-\mathrm{R}$ and. TN-W). The conserved structure of tenascins includes $\mathrm{N}$-terminal heptad repeats, EGF-like domains, and a series of fibronectin type-III domains that are important for the interaction between cell surface proteins and soluble factors in the ECM [125]. Tenascins are multifunctional MCPs that have 
been shown to mediate processes of cell adhesion, migration, matrix assembly, profibrotic cytokine upregulation, and myofibroblast differentiation [126-129]. In SSc research, the primary focus has been on TN-C because its translatable research from related fibrotic pathologies has provided a framework for study, whereas the other family members still remain undercharacterized.

TN-C expression is ubiquitously expressed during embryogenesis but may also display re-expression after fetal development in response to chronic inflammation at sites of wound healing and fibrosis [127]. The increased expression of TN-C in the reticular dermis in scleroderma has been observed through immunohistochemical techniques nearly three decades ago and has also been recently shown in the papillary layer as well $[130,131]$. TN-C is also a robust marker of SSc pathology not only in dermal skin but its elevated levels are also observed in serum and bronchoalveolar lavage fluid of SSc patients [132-134]. TN-C overexpression has been shown to accelerate SSc-related skin and pulmonary fibrosis, by driving tissue inflammation, myofibroblast differentiation, and aberrant deposition of collagen and fibronectin, subsequently leading to dermal stiffening [131,132]. To model SSc-associated acute lung injury, $\mathrm{TN}-\mathrm{C}$ knockout $\left(\mathrm{TN}_{-} \mathrm{C}^{--}\right)$mice were administered intratracheal bleomycin over a period of 14 days to induce fibrosis [131]. In such mice, a reduced fibrotic response was observed with less accumulation of $\alpha \mathrm{SMA}$-positive interstitial myofibroblasts in the lungs, as well as infiltration of inflammatory macrophages and lymphocytes, compared to vehicle-treated wild-type (WT) mice. Reduced collagen buildup and lysyl oxidase expression in the lungs also protected $\mathrm{TN}_{-} \mathrm{C}^{-/-}$mice from loss of lung elasticity due to tissue stiffening. Taken together, these findings suggest an overall fibrotic role of TN-C in pulmonary fibrosis. Within the same study, $\mathrm{TN}_{-} \mathrm{C}^{-1-}$ mice were also studied in conjunction with the Tsk1/+ model of noninflammatory associated skin fibrosis. TN-C $-1 / T s k 1 /+$ mice were generated, and it was found that the absence of TN-C slowed the onset of hypodermal thickening by reducing collagen and $\alpha \mathrm{SMA}$ expression, which is characteristic of this model [131].

A mechanism of TN-C-driven fibrogenesis in SSc has been shown in both stromal cells and macrophages through the action of toll-like receptors (TLRs), which are known to be activated in response to tissue injury [131]. Specifically, TN-C is capable of inducing a TLR4-dependent fibrotic response in fibroblasts, resulting in myofibroblast differentiation, collagen gene expression, secretion of Il-6, TGF $\beta$ regulation, and upregulation of TLR4 expression itself. Taken together, the aberrant accumulation of both TN-C and TLR4 within SSc lesional tissue is proposed to work co-operatively to create a feed-forward loop that amplifies TLR4 inflammatory and profibrotic signaling.

Although other members of the tenascin family have yet to be studied as extensively as TN-C, few studies have shown emerging roles of TN-X in SSc. Dermal fibroblasts cultured from TN-X-deficient $\left(\mathrm{TN}-\mathrm{X}^{-/}\right)$mice struggle to deposit sufficient amounts of type I collagen into the ECM, leading to reduced tensile strength and deformability in skin of $\mathrm{TN}^{-} \mathrm{X}^{-/-}$mice. Though the deposited collagen fibrils themselves did not exhibit morphological abnormalities, it suggests perhaps a role for TN-X as a regulator of collagen deposition and/or in determining mechanical properties of collagen-rich tissues, but not fibrillogenesis $[135,136]$.

\section{SIBLING Family}

The SIBLING family consists of five members; osteopontin (OPN/SPP1), bone sialoprotein (BSP), dentin sialophosphoprotein (DSPP), dentin matrix protein-1 (DMP1), and matrix extracellular phosphoglycoprotein (MEPE). All SIBLING proteins contain an Arg-Gly-Asp (RGD) integrin-binding motif important for its overall hydrophilic structure and cellular structure [137]. Most SIBLING proteins also activate specific MMPs to mediate processes involved in ECM degradation, and are best described in mineralized tissue such as bone and dentin [137,138]. OPN is the most studied SIBLING protein, and for this reason studies of this family within the context of SSc focuses mainly on OPN.

OPN expression is upregulated during wound repair where it serves to both initiate a proinflammatory response by localizing T-cells and macrophages at the site of injury, and regulate fibroblast behavior and myofibroblast differentiation during tissue remodeling [139]. Dysregulated OPN expression is associated with many fibrotic pathologies, and in vivo animal studies demonstrate that 
OPN inhibition significantly ameliorates fibrotic symptoms across different organ systems [140-142]. The improved fibrotic outcome is the result of several processes such as reduced collagen I/IV accumulation and matrix deposition, decreased local TGF $\beta$ activity, and lower myofibroblast proliferation. Unsurprisingly, these insights into the mechanisms of OPN have drawn attention to study them in SSc where a similar profibrotic role is described. Studies have shown that elevated levels of OPN has been found to be significantly higher in skin biopsies and circulating plasma for both dcSSc and lcSSc patients when compared to healthy controls [143-145]. Using an murine bleomycin-induced dermal fibrosis model, Wu et al. demonstrated that $\mathrm{OPN}^{-/-}$mice exhibit a reduced fibrotic and inflammatory response compared to WT counterparts [143]. Lesional skin biopsies revealed that $\mathrm{OPN}^{-/-}$animals have a decrease in dermal thickness, a reduced concentration of $\alpha \mathrm{SMA}$-expressing myofibroblasts, and less Mac-3-positive macrophages in the dermal layer. Such mice also have limited TGF $\beta$ expression in areas of lesional skin compared to WT animals, which likely contributes to the attenuated fibrotic response.

\section{Gla-Protein Family}

Periostin (POSTN) and matrix Gla protein (MGP) are two vitamin K-dependent $\gamma$-carboxyglutamic acid-containing proteins that reside in the ECM, and together with 17 other members, make up the MCP family known as the Gla-family. The Gla-family of proteins are known primarily for their importance to bone metabolism and calcification, but recently POSTN and MGP have also been demonstrated to be involved in the processes of ECM remodeling, wound repair, and cancer [56,146-149]. In the context of SSc, emphasis has been placed on elucidating the role of POSTN, whereas MGP is much less understood for its role as an MCP than that of its inhibition of calcification.

POSTN expression is consistently reported as being upregulated in SSc at varying stages of disease progression, and is detectable in serum and in biopsies of lesional skin, dermal, and lung primary fibroblasts [150-153]. Through analysis of serum POSTN, higher expression levels showed a positive correlation to both disease duration and severity of skin fibrosis [150]. Immunohistochemical staining for POSTN in SSc skin showed a concentrated localization in both the upper dermis and lower reticular layer where colocalization with $\alpha$ SMA-positive myofibroblasts was observed, indicating a potential association with the development of skin fibrosis [150]. Using an in vivo mouse model of bleomycin-induced scleroderma, knockout of POSTN (POSTN ${ }^{-/-}$mice) provided substantial protection against dermal thickening by limiting uncontrolled collagen deposition compared to WT mice [152]. Moreover, skin sections of POSTN ${ }^{-/-}$mice after bleomycin treatment contained fewer $\alpha$ SMA-positive cells compared to WT, suggesting that POSTN may be crucial for myofibroblast development in this model. Following up with in vitro experiments, isolated mouse dermal fibroblasts from POSTN $^{--}$mice were unable to sustain $\alpha$ SMA expression after TGF $\beta$ stimulation, compared to cultured fibroblasts from WT mice. Although an initial transient upregulation was observed, the enhanced $\alpha$ SMA expression was not upheld, suggesting that TGF $\beta$ requires the presence of POSTN for myofibroblast transformation. Lastly, immunohistochemical staining for POSTN in skin biopsy sections of scleroderma patients found POSTN expression to be entirely diffused throughout the dermis and subcutis layers [153]. As seen by confocal microscopy, POSTN was deposited within pockets of high $\alpha$ SMA concentration from these biopsy sections, in comparison to matched control samples.

MGP is a matrix-residing protein widely distributed in tissues including bone, kidney, lung, and cartilage, and is secreted by various cell types such as vascular smooth muscle cells and chondrocytes [154]. MGP is most notable for inhibiting vascular calcification through its five Gla-residues sequestering extracellular calcium ions and growth factors, such as bone morphogenetic proteins (BMP-2,4,7), in a vitamin K-dependent manner [155,156]. In SSc pathology, MGP is expressed in areas of dystrophic calcification, a frequently observed disease manifestation when deposits of calcified material occur in soft tissue [157]. Furthermore, it was found that MGP expression is upregulated in the skin of lcSSc patients with calcinosis compared to those without calcinosis [157]. A possible explanation for this observation may be that the gamma-carboxylation of MGP is required 
to prevent calcinosis by binding and inhibiting calcification-inducible factors. However, given that MGP has been recently described in tissue remodeling processes [146,149], further investigation is necessary to verify if a link exists between MGP expression and fibrosis in SSc.

\section{Therapeutic Implications of MCPs in SSc}

Extracellular localization, expression restricted to tissue remodeling processes, and strong association to disease progression are among the key characteristics of MCPs that offer inroads to be exploited in developing therapeutic tools and strategies. The clinical utility of MCPs are evolving beyond roles as merely informative biomarkers, which still remains an important exploratory route, but they are also being explored as drug delivery vehicles, therapeutic silencing targets, and components in biomaterials [158-160]. An informative review of MCPs and their burgeoning role as therapeutic targets in various disease contexts is referenced $[149,158]$. Herein, we summarize several recent examples of emerging therapeutic solutions that highlight the intersections between MCPs and SSc.

The CCN family has been a target of therapeutic interest since many of its studies have associated it to SSc more than any other MCP. Although several of the CCN members have contributed to fibrotic studies, CCN2 has had more success than any other member into transitioning clinically. A well-known human monoclonal neutralizing antibody inhibitor of CCN2, FG-3019, has been assessed in various disease models, including a model of murine Angiotensin-II-induced skin fibrosis [161]. A 2-week treatment with FG-3019 significantly reduced dermal thickness and collagen concentration versus control. FG-3019 treatment also reduced the fibrotic TGF $\beta$ pathway as evidenced by decreased phosphorylation of its downstream SMAD2 target. With a good outcome in a phase II trial (PRAISE, NCT01890265), FG-3019 is now currently proceeding into a phase III trial for idiopathic pulmonary fibrosis (NCT03955146), a frequent disease complication in SSc [162]. Pravastatin has recently been shown to also inhibit CCN2. Used as a specific inhibitor of the Rho/ROCK signaling pathway, pravastatin was found to impede CCN2 activation in ex vivo human intestinal tissue, which was further validated in rat models of intestinal fibrosis [163]. In fact, the direct downstream activation of CCN2 through the Rho/ROCK pathway by statin derivatives is a well noted observation [164]. Mechanistically, the inhibition of CCN2 mRNA and protein expression in pravastatin-treated rats limited deposition of type I collagen and fibronectin in a dose-dependent manner. The mounting evidence of CCN2 inhibition with repurposed drugs as an effective strategy for fibrotic management is encouraging because it provides a better understanding of the pharmacological mechanism of action of such treatments.

Although many more clinical studies are needed to prove the efficacy of targeting MCPs, promising therapeutic studies have provided evidence of indirectly lowering MCPs to affect SSc, implying cotargeting molecules for potential effective treatments. Fresolimumab is a TGF $\beta$-neutralizing antibody that targets all of its mammalian isoforms and has been successful in a phase I clinical trial of early dcSSc patients (NCT01284322), reducing SSc disease biomarkers and improving skin symptoms [94]. Fresolimumab treatment downregulated profibrotic genes CCN2, COL10A1, and SERPINE1 in skin biopsies, which also correlated with decreases in MRSS scores and dermal myofibroblast infiltration. Alongside MRSS scores, THBS- 1 and -5 were used to evaluate the efficacy of fresolimumab for its rapid decline of TGF $\beta$-regulated gene expressions, which demonstrated the capability of MCPs to serve as biomarkers in decision-making of tolerable drugs. Another recent study investigated the remedial properties of glycyrrhizin in a bleomycin mouse model of scleroderma. Treatment attributes included a blockage of key TGF $\beta$ transcription factors (SMAD3 and Ets1) along with a downregulation of THBS-1 in dermal fibroblasts, leading to significant amelioration of dermal fibrosis [165]. Targeting exosomes may also hold therapeutic potential to treating SSc, which would involve a mechanism implicating $\mathrm{MCP}$ expression Exosomes are nanovesicles composed of proteins and nucleic acids which have been shown to increase MCP expression in different fibrotic diseases, including SSc [166,167]. Compared to normal serum exosomes, isolated serum exosomes from SSc patients displayed higher levels of fibrotic microRNAs that were capable of increasing the expression of fibrotic genes, including CCN2 [168,169]. 
As we discover a larger number of MCP genes affected by exosomes in SSc, manipulating the contents, secretion, and delivery of such exosomes may prove to be effective in combating fibrosis from a therapeutic standpoint.

Beyond MCPs, several promising therapeutic interventions for managing SSc fibrosis have been reported but not yet validated in randomized controlled trials [170]. Drugs such as imatinib mesylate, pirfenidone, and rapamycin have shown antifibrotic potential in murine models of SSc skin and lung fibrosis, but a complete understanding is still lacking. Therefore, continued research and application of MCPs in sclerodermic models is wholly justified to efficiently develop therapeutic options that could be used independently or in combination of current treatments for effective options that impede and prevent fibrosis development.

\section{Conclusions}

The evidence has been promising to associate MCPs as essential contributors to the fibrotic pathophysiology in SSc. Each MCP family, albeit not every family member, has been shown to affect fibrotic processes in both primary and secondary roles by working in concert with profibrotic mechanisms such as TGF $\beta$ signaling, aberrant secretion of major ECM proteins (type I collagen and fibronectin), mechanotransduction, and myofibroblast differentiation. As the literature continues to expand and clarify many of the unaddressed mechanistic details of MCPs, parallels from related fibrotic pathologies may provide useful insights to translate into SSc [171]. This is especially true for the undercharacterized MCPs that lack direct studies investigating their roles in SSc or for proteins that currently serve a limited utility. MCPs have been emerging as reliable informative biomarkers in SSc since they are detectable in various forms of biological samples as well as holding their value in comparison to established metrics like the MRSS system. Future outlook of MCPs in SSc is promising with growing applications in clinical settings, as briefly highlighted in this review. Overall, research into the emerging roles of MCPs in SSc is an exciting endeavor owing to the breadth of known fibrotic functions that MCPs have in various organs, which will aid in defining their practical use in managing this vastly heterogenous disease.

Author Contributions: Writing—original draft preparation, D.F. and writing—review and editing, C.G. All authors have read and agreed to the published version of the manuscript.

Funding: The author(s) disclosed receipt of the following financial support for the research, authorship, and/or publication of this article: Casimiro Gerarduzzi is a recipient of the Kidney Research Scientist Core Education and National Training (KRESCENT) Program New Investigator Award (KRES180003; cofunded by the Kidney Foundation of Canada, Canadian Society of Nephrology, and Canadian Institutes of Health Research). The Casimiro Gerarduzzi laboratory is supported by the Canadian Institutes of Health Research (MOP-428250), the KRESCENT Infrastructure Support (KRES180004), and start-up funds from the Hôpital Maisonneuve-Rosemont Foundation.

Conflicts of Interest: The authors declare no conflicts of interest.

\section{Abbreviations}

SSc systemic sclerosis

dcSSc diffuse cutaneous systemic sclerosis

lcSSc limited cutaneous systemic sclerosis

ECM extracellular matrix

aSMA alpha-smooth muscle actin

MCP matricellular protein

$\mathrm{CCN} \quad$ centralized coordination network

THBS thrombospondin

SPARC secreted protein acidic and rich in cysteine

TN tenascin

SIBLING Small Integrin-Binding Ligand N-Linked Glycoprotein 


$\begin{array}{ll}\text { Gla } & \gamma \text {-carboxyglutamate } \\ \text { MMP } & \text { matrix metalloprotease } \\ \text { Tsk1/+ } & \text { tight skin 1 } \\ \text { MRSS } & \text { modified Rodnan skin score } \\ \text { HADC } & \text { histone deacetylase } \\ \text { EC } & \text { endothelial cell } \\ \text { WT } & \text { wild-type } \\ \text { TLR } & \text { toll-like receptor } \\ \text { OPN } & \text { osteopontin } \\ \text { POSTN } & \text { periostin } \\ \text { MGP } & \text { matrix Gla protein }\end{array}$

\section{References}

1. Pattanaik, D.; Brown, M.; Postlethwaite, B.C.; Postlethwaite, A.E. Pathogenesis of Systemic Sclerosis. Front. Immunol. 2015, 6, 272. [CrossRef] [PubMed]

2. Tyndall, A.J.; Bannert, B.; Vonk, M.; Airo, P.; Cozzi, F.; Carreira, P.E.; Bancel, D.F.; Allanore, Y.; Muller-Ladner, U.; Distler, O.; et al. Causes and risk factors for death in systemic sclerosis: A study from the EULAR Scleroderma Trials and Research (EUSTAR) database. Ann. Rheum. Dis. 2010, 69, 1809-1815. [CrossRef] [PubMed]

3. Simeon-Aznar, C.P.; Fonollosa-Pla, V.; Tolosa-Vilella, C.; Espinosa-Garriga, G.; Campillo-Grau, M.; Ramos-Casals, M.; Garcia-Hernandez, F.J.; Castillo-Palma, M.J.; Sanchez-Roman, J.; Callejas-Rubio, J.L.; et al. Registry of the Spanish Network for Systemic Sclerosis: Survival, Prognostic Factors, and Causes of Death. Medicine 2015, 94, e1728. [CrossRef] [PubMed]

4. Tomiyama, F.; Watanabe, R.; Ishii, T.; Kamogawa, Y.; Fujita, Y.; Shirota, Y.; Sugimura, K.; Fujii, H.; Harigae, H. High Prevalence of Acute Exacerbation of Interstitial Lung Disease in Japanese Patients with Systemic Sclerosis. Tohoku J. Exp. Med. 2016, 239, 297-305. [CrossRef] [PubMed]

5. Pokeerbux, M.R.; Giovannelli, J.; Dauchet, L.; Mouthon, L.; Agard, C.; Lega, J.C.; Allanore, Y.; Jego, P.; Bienvenu, B.; Berthier, S.; et al. Survival and prognosis factors in systemic sclerosis: Data of a French multicenter cohort, systematic review, and meta-analysis of the literature. Arthritis Res. Ther. 2019, 21, 86. [CrossRef]

6. Hu, S.; Hou, Y.; Wang, Q.; Li, M.; Xu, D.; Zeng, X. Prognostic profile of systemic sclerosis: Analysis of the clinical EUSTAR cohort in China. Arthritis Res. Ther. 2018, 20, 235. [CrossRef]

7. Poormoghim, H.; Andalib, E.; Jalali, A.; Ghaderi, A.; Ghorbannia, A.; Mojtabavi, N. Survival and causes of death in systemic sclerosis patients: A single center registry report from Iran. Rheumatol. Int. 2016, 36, 925-934. [CrossRef]

8. Affandi, A.J.; Radstake, T.R.; Marut, W. Update on biomarkers in systemic sclerosis: Tools for diagnosis and treatment. Semin. Immunopathol. 2015, 37, 475-487. [CrossRef]

9. Van der Kroef, M.; Van den Hoogen, L.L.; Mertens, J.S.; Blokland, S.L.M.; Haskett, S.; Devaprasad, A.; Carvalheiro, T.; Chouri, E.; Vazirpanah, N.; Cossu, M.; et al. Cytometry by time of flight identifies distinct signatures in patients with systemic sclerosis, systemic lupus erythematosus and Sjogrens syndrome. Eur. J. Immunol. 2020, 50, 119-129. [CrossRef]

10. Martyanov, V.; Whitfield, M.L. Molecular stratification and precision medicine in systemic sclerosis from genomic and proteomic data. Curr. Opin. Rheumatol. 2016, 28, 83-88. [CrossRef]

11. Wermuth, P.J.; Piera-Velazquez, S.; Rosenbloom, J.; Jimenez, S.A. Existing and novel biomarkers for precision medicine in systemic sclerosis. Nat. Rev. Rheumatol. 2018, 14, 421-432. [CrossRef]

12. Wynn, T.A. Common and unique mechanisms regulate fibrosis in various fibroproliferative diseases. J. Clin. Investig. 2007, 117, 524-529. [CrossRef]

13. Bonnans, C.; Chou, J.; Werb, Z. Remodelling the extracellular matrix in development and disease. Nat. Rev. Mol. Cell Biol. 2014, 15, 786-801. [CrossRef]

14. Steen, V.D.; Medsger, T.A. Changes in causes of death in systemic sclerosis, 1972-2002. Ann. Rheum. Dis. 2007, 66, 940-944. [CrossRef] [PubMed] 
15. Veraldi, K.L.; Hsu, E.; Feghali-Bostwick, C.A. Pathogenesis of pulmonary fibrosis in systemic sclerosis: Lessons from interstitial lung disease. Curr. Rheumatol. Rep. 2010, 12, 19-25. [CrossRef] [PubMed]

16. Rubio-Rivas, M.; Royo, C.; Simeón, C.P.; Corbella, X.; Fonollosa, V. Mortality and survival in systemic sclerosis: Systematic review and meta-analysis. Semin. Arthritis Rheum. 2014, 44, 208-219. [CrossRef] [PubMed]

17. Klingberg, F.; Hinz, B.; White, E.S. The myofibroblast matrix: Implications for tissue repair and fibrosis. J. Pathol. 2013, 229, 298-309. [CrossRef]

18. Leask, A. Matrix remodeling in systemic sclerosis. Semin. Immunopathol. 2015, 37, 559-563. [CrossRef]

19. Hinz, B.; Lagares, D. Evasion of apoptosis by myofibroblasts: A hallmark of fibrotic diseases. Nat. Rev. Rheumatol. 2020, 16, 11-31. [CrossRef]

20. Van Caam, A.; Vonk, M.; Van den Hoogen, F.; Van Lent, P.; Van der Kraan, P. Unraveling SSc Pathophysiology; The Myofibroblast. Front. Immunol. 2018, 9, 2452. [CrossRef]

21. Ebmeier, S.; Horsley, V. Origin of fibrosing cells in systemic sclerosis. Curr. Opin. Rheumatol. 2015, 27, 555-562. [CrossRef] [PubMed]

22. Lafyatis, R. Transforming growth factor $\beta$-At the centre of systemic sclerosis. Nat. Rev. Rheumatol. 2014, 10, 706-719. [CrossRef]

23. Raja, J.; Denton, C. Cytokines in the immunopathology of systemic sclerosis. Semin. Immunopathol. 2015, 37, 543-557. [CrossRef] [PubMed]

24. Pannu, J.; Nakerakanti, S.; Smith, E.; Ten Dijke, P.; Trojanowska, M. Transforming growth factor-beta receptor type I-dependent fibrogenic gene program is mediated via activation of Smad1 and ERK1/2 pathways. J. Biol. Chem. 2007, 282, 10405-10413. [CrossRef]

25. Li, Y.; Huang, J.; Guo, M.; Zuo, X. MicroRNAs Regulating Signaling Pathways: Potential Biomarkers in Systemic Sclerosis. Genom. Proteom. Bioinform. 2015, 13, 234-241. [CrossRef] [PubMed]

26. Piersma, B.; Bank, R.A.; Boersema, M. Signaling in Fibrosis: TGF- $\beta$, WNT, and YAP/TAZ Converge. Front. Med. 2015, 2, 59. [CrossRef] [PubMed]

27. Bergmann, C.; Distler, J.H. Canonical Wnt signaling in systemic sclerosis. Lab. Investig. 2016, 96, 151-155. [CrossRef]

28. Burgy, O.; Königshoff, M. The WNT signaling pathways in wound healing and fibrosis. Matrix Biol. 2018, 68-69, 67-80. [CrossRef]

29. Sage, E.H.; Bornstein, P. Extracellular proteins that modulate cell-matrix interactions. SPARC, tenascin, and thrombospondin. J. Biol. Chem. 1991, 266, 14831-14834.

30. Ma, Y.; Brás, L.E.d.; Toba, H.; Iyer, R.P.; Hall, M.E.; Winniford, M.D.; Lange, R.A.; Tyagi, S.C.; Lindsey, M.L. Myofibroblasts and the extracellular matrix network in post-myocardial infarction cardiac remodeling. Pflugers Arch. 2014, 466, 1113-1127. [CrossRef]

31. Rotstein, B.; Post, Y.; Reinhardt, M.; Lammers, K.; Buhr, A.; Heinisch, J.J.; Meyer, H.; Paululat, A. Distinct domains in the matricellular protein Lonely heart are crucial for cardiac extracellular matrix formation and heart function in Drosophila. J. Biol. Chem. 2018, 293, 7864-7879. [CrossRef] [PubMed]

32. Arora, P.; Vasa, P.; Brenner, D.; Iglar, K.; McFarlane, P.; Morrison, H.; Badawi, A. Prevalence estimates of chronic kidney disease in Canada: Results of a nationally representative survey. CMAJ 2013, 185, E417-E423. [CrossRef]

33. DiPersio, C.M.; Zheng, R.; Kenney, J.; Van de Water, L. Integrin-mediated regulation of epidermal wound functions. Cell Tissue Res. 2016, 365, 467-482. [CrossRef] [PubMed]

34. Leask, A. Conjunction junction, what's the function? CCN proteins as targets in fibrosis and cancers. Am. J. Physiol. Cell Physiol. 2020, 318, C1046-C1054. [CrossRef]

35. Lau, L.F. Cell surface receptors for CCN proteins. J. Cell Commun. Signal 2016, 10, 121-127. [CrossRef] [PubMed]

36. Murphy-Ullrich, J.E.; Sage, E.H. Revisiting the matricellular concept. Matrix Biol. 2014, 37, 1-14. [CrossRef] [PubMed]

37. Adams, J.C.; Kureishy, N.; Taylor, A.L. A role for syndecan-1 in coupling fascin spike formation by thrombospondin-1. J. Cell Biol. 2001, 152, 1169-1182. [CrossRef]

38. Goicoechea, S.; Murphy-Ullrich, J. Cell Surface Calreticulin: Role in Signaling Thrombospondin Anti-Adhesive Activity. In Madam Curie Bioscience Database; Landes Bioscience: Austin, TX, USA, 2014.

39. Gao, Q.; Chen, K.; Gao, L.; Zheng, Y.; Yang, Y.G. Thrombospondin-1 signaling through CD47 inhibits cell cycle progression and induces senescence in endothelial cells. Cell Death Dis. 2016, 7, e2368. [CrossRef] 
40. Mir, F.A.; Contreras-Ruiz, L.; Masli, S. Thrombospondin-1-dependent immune regulation by transforming growth factor- $\beta 2$-exposed antigen-presenting cells. Immunology 2015, 146, 547-556. [CrossRef]

41. Shirasaki, T.; Honda, M.; Yamashita, T.; Nio, K.; Shimakami, T.; Shimizu, R.; Nakasyo, S.; Murai, K.; Shirasaki, N.; Okada, H.; et al. The osteopontin-CD44 axis in hepatic cancer stem cells regulates IFN signaling and HCV replication. Sci. Rep. 2018, 8, 13143. [CrossRef]

42. Jun, J.I.; Lau, L.F. Taking aim at the extracellular matrix: CCN proteins as emerging therapeutic targets. Nat. Rev. Drug Discov. 2011, 10, 945-963. [CrossRef] [PubMed]

43. Van Obberghen-Schilling, E.; Tucker, R.P.; Saupe, F.; Gasser, I.; Cseh, B.; Orend, G. Fibronectin and tenascin-C: Accomplices in vascular morphogenesis during development and tumor growth. Int. J. Dev. Biol. 2011, 55, 511-525. [CrossRef]

44. Brellier, F.; Chiquet-Ehrismann, R. How do tenascins influence the birth and life of a malignant cell? J. Cell Mol. Med. 2012, 16, 32-40. [CrossRef]

45. Stephens, S.; Palmer, J.; Konstantinova, I.; Pearce, A.; Jarai, G.; Day, E. A functional analysis of Wnt inducible signalling pathway protein -1 (WISP-1/CCN4). J. Cell Commun. Signal. 2015, 9, 63-72. [CrossRef]

46. Haque, I.; Banerjee, S.; De, A.; Maity, G.; Sarkar, S.; Majumdar, M.; Jha, S.S.; McGragor, D.; Banerjee, S.K. CCN5/WISP-2 promotes growth arrest of triple-negative breast cancer cells through accumulation and trafficking of p27(Kip1) via Skp2 and FOXO3a regulation. Oncogene 2015, 34,3152-3163. [CrossRef] [PubMed]

47. Lawler, P.R.; Lawler, J. Molecular basis for the regulation of angiogenesis by thrombospondin-1 and -2 . Cold Spring Harb. Perspect. Med. 2012, 2, a006627. [CrossRef] [PubMed]

48. Isenberg, J.S.; Martin-Manso, G.; Maxhimer, J.B.; Roberts, D.D. Regulation of nitric oxide signalling by thrombospondin 1: Implications for anti-angiogenic therapies. Nat. Rev. Cancer 2009, 9, 182-194. [CrossRef] [PubMed]

49. Frolova, E.G.; Pluskota, E.; Krukovets, I.; Burke, T.; Drumm, C.; Smith, J.D.; Blech, L.; Febbraio, M.; Bornstein, P.; Plow, E.F.; et al. Thrombospondin-4 regulates vascular inflammation and atherogenesis. Circ. Res. 2010, 107, 1313-1325. [CrossRef]

50. Vanhoutte, D.; Schips, T.G.; Kwong, J.Q.; Davis, J.; Tjondrokoesoemo, A.; Brody, M.J.; Sargent, M.A.; Kanisicak, O.; Yi, H.; Gao, Q.Q.; et al. Thrombospondin expression in myofibers stabilizes muscle membranes. Elife 2016, 5, e17589. [CrossRef]

51. Chen, F.H.; Thomas, A.O.; Hecht, J.T.; Goldring, M.B.; Lawler, J. Cartilage oligomeric matrix protein/thrombospondin 5 supports chondrocyte attachment through interaction with integrins. J. Biol. Chem. 2005, 280, 32655-32661. [CrossRef]

52. Gerarduzzi, C.; Kumar, R.K.; Trivedi, P.; Ajay, A.K.; Iyer, A.; Boswell, S.; Hutchinson, J.N.; Waikar, S.S.; Vaidya, V.S. Silencing SMOC2 ameliorates kidney fibrosis by inhibiting fibroblast to myofibroblast transformation. JCI Insight 2017, 2, 8. [CrossRef] [PubMed]

53. Viloria, K.; Munasinghe, A.; Asher, S.; Bogyere, R.; Jones, L.; Hill, N.J. A holistic approach to dissecting SPARC family protein complexity reveals FSTL-1 as an inhibitor of pancreatic cancer cell growth. Sci. Rep. 2016, 6, 37839. [CrossRef] [PubMed]

54. Cheng, S.; Huang, Y.; Lou, C.; He, Y.; Zhang, Y.; Zhang, Q. FSTL1 enhances chemoresistance and maintains stemness in breast cancer cells via integrin $\beta 3 /$ Wnt signaling under miR-137 regulation. Cancer Biol. Ther. 2019, 20, 328-337. [CrossRef] [PubMed]

55. Zhao, H.; Chen, Q.; Alam, A.; Cui, J.; Suen, K.C.; Soo, A.P.; Eguchi, S.; Gu, J.; Ma, D. The role of osteopontin in the progression of solid organ tumour. Cell Death Dis. 2018, 9, 356. [CrossRef] [PubMed]

56. González-González, L.; Alonso, J. Periostin: A Matricellular Protein with Multiple Functions in Cancer Development and Progression. Front. Oncol. 2018, 8, 225. [CrossRef] [PubMed]

57. Perbal, B. The concept of the CCN protein family revisited: A centralized coordination network. J. Cell Commun. Signal. 2018, 12, 3-12. [CrossRef]

58. Rittié, L.; Perbal, B.; Castellot, J.J.; Orringer, J.S.; Voorhees, J.J.; Fisher, G.J. Spatial-temporal modulation of CCN proteins during wound healing in human skin in vivo. J. Cell Commun. Signal. 2011, 5, 69-80. [CrossRef]

59. Riser, B.L.; Barnes, J.L.; Varani, J. Balanced regulation of the CCN family of matricellular proteins: A novel approach to the prevention and treatment of fibrosis and cancer. J. Cell Commun. Signal. 2015, 9, 327-339. [CrossRef] 
60. Henrot, P.; Truchetet, M.E.; Fisher, G.; Taieb, A.; Cario, M. CCN proteins as potential actionable targets in scleroderma. Exp. Dermatol. 2019, 28, 11-18. [CrossRef]

61. Kim, K.H.; Won, J.H.; Cheng, N.; Lau, L.F. The matricellular protein CCN1 in tissue injury repair. J. Cell Commun. Signal. 2018, 12, 273-279. [CrossRef]

62. Lin, J.; Li, N.; Chen, H.; Liu, C.; Yang, B.; Ou, Q. Serum Cyr61 is associated with clinical disease activity and inflammation in patients with systemic lupus erythematosus. Medicine 2015, 94, e834. [CrossRef] [PubMed]

63. Tsou, P.S.; Khanna, D.; Sawalha, A.H. Identification of Cysteine-Rich Angiogenic Inducer 61 as a Potential Antifibrotic and Proangiogenic Mediator in Scleroderma. Arthritis Rheumatol. 2019, 71, 1350-1359. [CrossRef] [PubMed]

64. Saigusa, R.; Asano, Y.; Taniguchi, T.; Yamashita, T.; Takahashi, T.; Ichimura, Y.; Toyama, T.; Tamaki, Z.; Tada, Y.; Sugaya, M.; et al. A possible contribution of endothelial CCN1 downregulation due to Fli1 deficiency to the development of digital ulcers in systemic sclerosis. Exp. Dermatol. 2015, 24, 127-132. [CrossRef] [PubMed]

65. Quensel, K.; Shi-wen, X.; Hutchenreuther, J.; Xiao, Y.; Liu, S.; Peidl, A.; Naskar, D.; Siqueira, W.L.; O'Gorman, D.B.; Hinz, B.; et al. CCN1 expression by fibroblasts is required for bleomycin-inducedskin fibrosis. Matrix Biol. Plus 2019, 3, 100009.

66. Leask, A.; Parapuram, S.K.; Shi-Wen, X.; Abraham, D.J. Connective tissue growth factor (CTGF, CCN2) gene regulation: A potent clinical bio-marker of fibroproliferative disease? J. Cell Commun. Signal. 2009, 3, 89-94. [CrossRef]

67. Dendooven, A.; Gerritsen, K.G.; Nguyen, T.Q.; Kok, R.J.; Goldschmeding, R. Connective tissue growth factor (CTGF/CCN2) ELISA: A novel tool for monitoring fibrosis. Biomarkers 2011, 16, 289-301. [CrossRef] [PubMed]

68. Bassyuoni, I.H.; El-Shazly, R.; Elessawi, D.F.; Abou-Elalla, A.A. Soluble CCN2/Connective Tissue Growth Factor Levels in Egyptian Systemic Sclerosis Patients: Possible Association with Cutaneous and Pulmonary Fibrosis; Elesevier: Amsterdam, The Netherlands, 2019.

69. Dziadzio, M.; Usinger, W.; Leask, A.; Abraham, D.; Black, C.M.; Denton, C.; Stratton, R. N-terminal connective tissue growth factor is a marker of the fibrotic phenotype in scleroderma. QJM 2005, 98, 485-492. [CrossRef]

70. Shi-wen, X.; Pennington, D.; Holmes, A.; Leask, A.; Bradham, D.; Beauchamp, J.R.; Fonseca, C.; Bois, R.M.d.; Martin, G.R.; Black, C.M.; et al. Autocrine overexpression of CTGF maintains fibrosis: RDA analysis of fibrosis genes in systemic sclerosis. Exp. Cell Res. 2000, 259, 213-224. [CrossRef]

71. Nikitorowicz-Buniak, J.; Shiwen, X.; Denton, C.P.; Abraham, D.; Stratton, R. Abnormally differentiating keratinocytes in the epidermis of systemic sclerosis patients show enhanced secretion of CCN2 and S100A9. J. Investig. Dermatol. 2014, 134, 2693-2702. [CrossRef]

72. Leask, A.; Denton, C.; Abraham, D.J. Insights into the molecular mechanism of chronic fibrosis: The role of connective tissue growth factor in scleroderma. J. Investig. Dermatol. 2004, 122, 1-6. [CrossRef]

73. Trojanowska, M.; Varga, J.; Denton, C.; Wigley, F.; Allanore, Y.; Kuwana, M. Pathophysiology of Fibrosis in Systemic Sclerosis. In Scleroderma; Springer: Cham, Switzerland, 2017.

74. Bogatkevich, G.S.; Ludwicka-Bradley, A.; Nietert, P.J.; Silver, R.M. Scleroderma Lung Fibroblasts: Contractility and Connective Tissue Growth Factor; Gabbiani, G., Desmouliere, A., Eds.; Landes Bioscience: Austin, TX, USA, 2006; pp. 25-31.

75. Shiwen, X.; Stratton, R.; Nikitorowicz-Buniak, J.; Ahmed-Abdi, B.; Ponticos, M.; Denton, C.; Abraham, D.; Takahashi, A.; Suki, B.; Layne, M.D.; et al. A Role of Myocardin Related Transcription Factor-A (MRTF-A) in Scleroderma Related Fibrosis. PLoS ONE 2015, 10, e0126015. [CrossRef] [PubMed]

76. Toyama, T.; Looney, A.P.; Baker, B.M.; Stawski, L.; Haines, P.; Simms, R.; Szymaniak, A.D.; Varelas, X.; Trojanowska, M. Therapeutic Targeting of TAZ and YAP by Dimethyl Fumarate in Systemic Sclerosis Fibrosis. J. Investig. Dermatol. 2018, 138, 78-88. [CrossRef] [PubMed]

77. Abd El Kader, T.; Kubota, S.; Janune, D.; Nishida, T.; Hattori, T.; Aoyama, E.; Perbal, B.; Kuboki, T.; Takigawa, M. Anti-fibrotic effect of CCN3 accompanied by altered gene expression profile of the CCN family. J. Cell Commun. Signal. 2013, 7, 11-18. [CrossRef] [PubMed]

78. Riser, B.L.; Najmabadi, F.; Perbal, B.; Peterson, D.R.; Rambow, J.A.; Riser, M.L.; Sukowski, E.; Yeger, H.; Riser, S.C. CCN3 (NOV) is a negative regulator of CCN2 (CTGF) and a novel endogenous inhibitor of the fibrotic pathway in an in vitro model of renal disease. Am. J. Pathol. 2009, 174, 1725-1734. [CrossRef] [PubMed] 
79. Lemaire, R.; Farina, G.; Bayle, J.; Dimarzio, M.; Pendergrass, S.A.; Milano, A.; Perbal, B.; Whitfield, M.L.; Lafyatis, R. Antagonistic effect of the matricellular signaling protein CCN3 on TGF-beta- and Wnt-mediated fibrillinogenesis in systemic sclerosis and Marfan syndrome. J. Investig. Dermatol. 2010, 130, 1514-1523. [CrossRef]

80. Li, X.; Chen, Y.; Ye, W.; Tao, X.; Zhu, J.; Wu, S.; Lou, L. Blockade of CCN4 attenuates CCl4-induced liver fibrosis. Arch. Med. Sci. 2015, 11, 647-653. [CrossRef] [PubMed]

81. Jeong, D.; Lee, M.A.; Li, Y.; Yang, D.K.; Kho, C.; Oh, J.G.; Hong, G.; Lee, A.; Song, M.H.; LaRocca, T.J.; et al. Matricellular Protein CCN5 Reverses Established Cardiac Fibrosis. J. Am. Coll. Cardiol. 2016, 67, 1556-1568. [CrossRef]

82. Gardner, H.; Shearstone, J.R.; Bandaru, R.; Crowell, T.; Lynes, M.; Trojanowska, M.; Pannu, J.; Smith, E.; Jablonska, S.; Blaszczyk, M.; et al. Gene profiling of scleroderma skin reveals robust signatures of disease that are imperfectly reflected in the transcript profiles of explanted fibroblasts. Arthritis Rheum. 2006, 54, 1961-1973. [CrossRef]

83. Bhattacharyya, S.; Sargent, J.L.; Du, P.; Lin, S.; Tourtellotte, W.G.; Takehara, K.; Whitfield, M.L.; Varga, J. Egr-1 induces a profibrotic injury/repair gene program associated with systemic sclerosis. PLoS ONE 2011, 6, e23082. [CrossRef]

84. Homer, R.J.; Herzog, E.L. Recent advances in pulmonary fibrosis: Implications for scleroderma. Curr. Opin. Rheumatol. 2010, 22, 683-689. [CrossRef]

85. Akter, T.; Silver, R.M.; Bogatkevich, G.S. Recent advances in understanding the pathogenesis of scleroderma-interstitial lung disease. Curr. Rheumatol. Rep. 2014, 16, 411. [CrossRef] [PubMed]

86. Carlson, C.B.; Lawler, J.; Mosher, D.F. Structures of thrombospondins. Cell Mol. Life Sci. 2008, 65, 672-686. [CrossRef] [PubMed]

87. Adams, J.C.; Lawler, J. The thrombospondins. Cold Spring Harb. Perspect. Biol. 2011, 3, a009712. [CrossRef] [PubMed]

88. Chistiakov, D.A.; Melnichenko, A.A.; Myasoedova, V.A.; Grechko, A.V.; Orekhov, A.N. Thrombospondins: A Role in Cardiovascular Disease. Int. J. Mol. Sci. 2017, 18, 1540. [CrossRef] [PubMed]

89. Kazerounian, S.; Lawler, J. Integration of pro- and anti-angiogenic signals by endothelial cells. J. Cell Commun. Signal. 2018, 12, 171-179. [CrossRef] [PubMed]

90. Murphy-Ullrich, J.E.; Suto, M.J. Thrombospondin-1 regulation of latent TGF- $\beta$ activation: A therapeutic target for fibrotic disease. Matrix Biol. 2018, 68-69, 28-43. [CrossRef] [PubMed]

91. Rice, L.M.; Ziemek, J.; Stratton, E.A.; McLaughlin, S.R.; Padilla, C.M.; Mathes, A.L.; Christmann, R.B.; Stifano, G.; Browning, J.L.; Whitfield, M.L.; et al. A longitudinal biomarker for the extent of skin disease in patients with diffuse cutaneous systemic sclerosis. Arthritis Rheumatol. 2015, 67, 3004-3015. [CrossRef]

92. Farina, G.; Lafyatis, D.; Lemaire, R.; Lafyatis, R. A four-gene biomarker predicts skin disease in patients with diffuse cutaneous systemic sclerosis. Arthritis Rheum. 2010, 62, 580-588. [CrossRef]

93. Ligon, C.; Hummers, L.K. Biomarkers in Scleroderma: Progressing from Association to Clinical Utility. Curr. Rheumatol. Rep. 2016, 18, 17. [CrossRef]

94. Rice, L.M.; Padilla, C.M.; McLaughlin, S.R.; Mathes, A.; Ziemek, J.; Goummih, S.; Nakerakanti, S.; York, M.; Farina, G.; Whitfield, M.L.; et al. Fresolimumab treatment decreases biomarkers and improves clinical symptoms in systemic sclerosis patients. J. Clin. Investig. 2015, 125, 2795-2807. [CrossRef]

95. Rice, L.M.; Sno, G.; Ziemek, J.; Lafyatis, R. Local skin gene expression reflects both local and systemic skin disease in patients with systemic sclerosis. Rheumatology 2016, 55, 377-379. [CrossRef] [PubMed]

96. Chen, Y.; Leask, A.; Abraham, D.J.; Kennedy, L.; Xu, S.-W.; Denton, C.P.; Black, C.M.; Verjee, L.S.; Eastwood, M. Wnt signaling under miR-137 regulation Thrombospondin 1 is a key mediator of transforming growth factor $\beta$-mediated cell contractility in systemic sclerosis via a mitogen-activated protein kinase kinase (MEK)/extracellular signal-regulated kinase (ERK)-dependent mechanism. Fibrogenes. Tissue Repair 2011, 4, 9.

97. Xu, X.; Khoong, Y.M.; Gu, S.; Huang, X.; Ren, J.Y.; Gu, Y.H.; Li, H.; Gao, Y.; Wang, Z.; Zan, T. Investigating the potential of LSKL peptide as a novel hypertrophic scar treatment. Biomed. Pharmacother. 2020, 124, 109824. [CrossRef] [PubMed]

98. Kyriakides, T.R.; Zhu, Y.H.; Smith, L.T.; Bain, S.D.; Yang, Z.; Lin, M.T.; Danielson, K.G.; Iozzo, R.V.; LaMarca, M.; McKinney, C.E.; et al. Mice that lack thrombospondin 2 display connective tissue abnormalities that are associated with disordered collagen fibrillogenesis, an increased vascular density, and a bleeding diathesis. J. Cell Biol. 1998, 140, 419-430. [CrossRef] [PubMed] 
99. Kyriakides, T.R.; Tam, J.W.; Bornstein, P. Accelerated wound healing in mice with a disruption of the thrombospondin 2 gene. J. Investig. Dermatol. 1999, 113, 782-787. [CrossRef] [PubMed]

100. Kajihara, I.; Jinnin, M.; Yamane, K.; Makino, T.; Honda, N.; Igata, T.; Masuguchi, S.; Fukushima, S.; Okamoto, Y.; Hasegawa, M.; et al. Increased accumulation of extracellular thrombospondin-2 due to low degradation activity stimulates type I collagen expression in scleroderma fibroblasts. Am. J. Pathol. 2012, 180, 703-714. [CrossRef] [PubMed]

101. Halász, K.; Kassner, A.; Mörgelin, M.; Heinegård, D. COMP acts as a catalyst in collagen fibrillogenesis. J. Biol. Chem. 2007, 282, 31166-31173. [CrossRef]

102. Agarwal, P.; Zwolanek, D.; Keene, D.R.; Schulz, J.N.; Blumbach, K.; Heinegård, D.; Zaucke, F.; Paulsson, M.; Krieg, T.; Koch, M.; et al. Collagen XII and XIV, new partners of cartilage oligomeric matrix protein in the skin extracellular matrix suprastructure. J. Biol. Chem. 2012, 287, 22549-22559. [CrossRef] [PubMed]

103. Acharya, C.; Yik, J.H.; Kishore, A.; Van Dinh, V.; Di Cesare, P.E.; Haudenschild, D.R. Cartilage oligomeric matrix protein and its binding partners in the cartilage extracellular matrix: Interaction, regulation and role in chondrogenesis. Matrix Biol. 2014, 37, 102-111. [CrossRef]

104. Schulz, J.N.; Nüchel, J.; Niehoff, A.; Bloch, W.; Schönborn, K.; Hayashi, S.; Kamper, M.; Brinckmann, J.; Plomann, M.; Paulsson, M.; et al. COMP-assisted collagen secretion-A novel intracellular function required for fibrosis. J. Cell Sci. 2016, 129, 706-716. [CrossRef]

105. Posey, K.L.; Coustry, F.; Hecht, J.T. Cartilage oligomeric matrix protein: COMPopathies and beyond. Matrix Biol. 2018, 71-72, 161-173. [CrossRef] [PubMed]

106. Hesselstrand, R.; Andreasson, K.; Wuttge, D.M.; Bozovic, G.; Scheja, A.; Saxne, T. Increased serum COMP predicts mortality in SSc: Results from a longitudinal study of interstitial lung disease. Rheumatology 2012, 51, 915-920. [CrossRef] [PubMed]

107. Hesselstrand, R.; Carlestam, J.; Wildt, M.; Sandqvist, G.; Andreasson, K. High frequency ultrasound of skin involvement in systemic sclerosis-A follow-up study. Arthritis Res. Ther. 2015, 17, 329. [CrossRef] [PubMed]

108. Farina, G.; Lemaire, R.; Korn, J.H.; Widom, R.L. Cartilage oligomeric matrix protein is overexpressed by scleroderma dermal fibroblasts. Matrix Biol. 2006, 25, 213-222. [CrossRef]

109. Frolova, E.G.; Sopko, N.; Blech, L.; Popovic, Z.B.; Li, J.; Vasanji, A.; Drumm, C.; Krukovets, I.; Jain, M.K.; Penn, M.S.; et al. Thrombospondin-4 regulates fibrosis and remodeling of the myocardium in response to pressure overload. FASEB J. 2012, 26, 2363-2373. [CrossRef] [PubMed]

110. Muppala, S.; Frolova, E.; Xiao, R.; Krukovets, I.; Yoon, S.; Hoppe, G.; Vasanji, A.; Plow, E.; Stenina-Adognravi, O. Proangiogenic Properties of Thrombospondin-4. Arterioscler. Thromb. Vasc. Biol. 2015, 35, 1975-1986. [CrossRef]

111. Moon, S.J.; Bae, J.M.; Park, K.S.; Tagkopoulos, I.; Kim, K.J. Compendium of skin molecular signatures identifies key pathological features associated with fibrosis in systemic sclerosis. Ann. Rheum. Dis. 2019, 78, 817-825. [CrossRef]

112. Bradshaw, A.D. Diverse biological functions of the SPARC family of proteins. Int. J. Biochem. Cell Biol. 2012, 44, 480-488. [CrossRef]

113. Gagliardi, F.; Narayanan, A.; Mortini, P. SPARCL1 a novel player in cancer biology. Crit. Rev. Oncol. Hematol. 2017, 109, 63-68. [CrossRef]

114. Zhao, P.; Guan, H.T.; Dai, Z.J.; Ma, Y.G.; Liu, X.X.; Wang, X.J. Knockdown of SPOCK1 Inhibits the Proliferation and Invasion in Colorectal Cancer Cells by Suppressing the PI3K/Akt Pathway. Oncol. Res. 2016, 24, 437-445. [CrossRef]

115. Trombetta-Esilva, J.; Bradshaw, A.D. The Function of SPARC as a Mediator of Fibrosis. Open Rheumatol. J. 2012, 6, 146-155. [CrossRef] [PubMed]

116. Macko, R.F.; Gelber, A.C.; Young, B.A.; Lowitt, M.H.; White, B.; Wigley, F.M.; Goldblum, S.E. Increased circulating concentrations of the counteradhesive proteins SPARC and thrombospondin-1 in systemic sclerosis (scleroderma). Relationship to platelet and endothelial cell activation. J. Rheumatol. 2002, 29, 2565-2570. [PubMed]

117. Zhou, X.; Tan, F.K.; Guo, X.; Arnett, F.C. Attenuation of collagen production with small interfering RNA of SPARC in cultured fibroblasts from the skin of patients with scleroderma. Arthritis Rheum. 2006, 54, 2626-2631. [CrossRef] [PubMed] 
118. Carvalheiro, T.; Fernández, B.M.; Ottria, A.; Giovannone, B.; Marut, W.; Reedquist, K.A.; Garcia, S.; Radstake, T.R. Extracellular SPARC cooperates with TGF- $\beta$ signalling to induce pro-fibrotic activation of systemic sclerosis patient dermal fibroblasts. Rheumatology 2019, kez583. [CrossRef]

119. Zhou, X.; Tan, F.K.; Reveille, J.D.; Wallis, D.; Milewicz, D.M.; Ahn, C.; Wang, A.; Arnett, F.C. Association of novel polymorphisms with the expression of SPARC in normal fibroblasts and with susceptibility to scleroderma. Arthritis Rheum. 2002, 46, 2990-2999. [CrossRef]

120. Li, D.; Wang, Y.; Xu, N.; Wei, Q.; Wu, M.; Li, X.; Zheng, P.; Sun, S.; Jin, Y.; Zhang, G.; et al. Follistatin-like protein 1 is elevated in systemic autoimmune diseases and correlated with disease activity in patients with rheumatoid arthritis. Arthritis Res. Ther. 2011, 13, R17. [CrossRef]

121. Tsou, P.S.; Wren, J.D.; Amin, M.A.; Schiopu, E.; Fox, D.A.; Khanna, D.; Sawalha, A.H. Histone Deacetylase 5 Is Overexpressed in Scleroderma Endothelial Cells and Impairs Angiogenesis via Repression of Proangiogenic Factors. Arthritis Rheumatol. 2016, 68, 2975-2985. [CrossRef] [PubMed]

122. Zheng, X.; Qi, C.; Zhang, S.; Fang, Y.; Ning, W. TGF- $\beta 1$ induces Fstl1 via the Smad3-c-Jun pathway in lung fibroblasts. Am. J. Physiol. Lung Cell Mol. Physiol. 2017, 313, L240-L251. [CrossRef]

123. Vollmann, E.H.; Cao, L.; Amatucci, A.; Reynolds, T.; Hamann, S.; Dalkilic-Liddle, I.; Cameron, T.O.; Hossbach, M.; Kauffman, K.J.; Mir, F.F.; et al. Identification of Novel Fibrosis Modifiers by In Vivo siRNA Silencing. Mol. Ther. Nucleic Acids 2017, 7, 314-323. [CrossRef]

124. Hayakawa, S.; Ohashi, K.; Shibata, R.; Kataoka, Y.; Miyabe, M.; Enomoto, T.; Joki, Y.; Shimizu, Y.; Kambara, T.; Uemura, Y.; et al. Cardiac myocyte-derived follistatin-like 1 prevents renal injury in a subtotal nephrectomy model. J. Am. Soc. Nephrol. 2015, 26, 636-646. [CrossRef]

125. Jones, F.S.; Jones, P.L. The tenascin family of ECM glycoproteins: Structure, function, and regulation during embryonic development and tissue remodeling. Dev. Dyn. 2000, 218, 235-259. [CrossRef]

126. Valcourt, U.; Alcaraz, L.B.; Exposito, J.Y.; Lethias, C.; Bartholin, L. Tenascin-X: Beyond the architectural function. Cell Adh. Migr. 2015, 9, 154-165. [CrossRef]

127. Giblin, S.; Midwood, K.S. Tenascin-C: Form. versus function. Cell Adh. Migr. 2015, 9, 48-82. [CrossRef] [PubMed]

128. Liao, H.; Bu, W.Y.; Wang, T.H.; Ahmed, S.; Xiao, Z.C. Tenascin-R plays a role in neuroprotection via its distinct domains that coordinate to modulate the microglia function. J. Biol. Chem. 2005, 280, 8316-8323. [CrossRef]

129. Tucker, R.; Degen, M. The Expression and Possible Functions of Tenascin-W During Development and Disease. Front. Cell Dev. Biol. 2019, 7, 53. [CrossRef] [PubMed]

130. Lacour, J.P.; Vitetta, A.; Chiquet-Ehrismann, R.; Pisani, A.; Ortonne, J.P. Increased expression of tenascin in the dermis in scleroderma. Br. J. Dermatol. 1992, 127, 328-334. [CrossRef] [PubMed]

131. Bhattacharyya, S.; Wang, W.; Morales-Nebreda, L.; Feng, G.; Wu, M.; Zhou, X.; Lafyatis, R.; Lee, J.; Hinchcliff, M.; Feghali-Bostwick, C.; et al. Tenascin-C drives persistence of organ fibrosis. Nat. Commun. 2016, 7, 11703. [CrossRef] [PubMed]

132. Brissett, M.; Veraldi, K.L.; Pilewski, J.M.; Medsger, T.A.; Feghali-Bostwick, C.A. Localized expression of tenascin in systemic sclerosis-associated pulmonary fibrosis and its regulation by insulin-like growth factor binding protein 3. Arthritis Rheum. 2012, 64, 272-280. [CrossRef] [PubMed]

133. Inoue, K.; Jinnin, M.; Hara, Y.; Makino, K.; Kajihara, I.; Makino, T.; Sakai, K.; Fukushima, S.; Inoue, Y.; Ihn, H. Serum levels of tenascin-C in collagen diseases. J. Dermatol. 2013, 40, 715-719. [CrossRef] [PubMed]

134. Tourkina, E.; Hoffman, S.; Fenton, J.W.; Lipsitz, S.; Silver, R.M.; Ludwicka-Bradley, A. Depletion of protein kinase Cepsilon in normal and scleroderma lung fibroblasts has opposite effects on tenascin expression. Arthritis Rheum. 2001, 44, 1370-1381. [CrossRef]

135. Mao, J.R.; Taylor, G.; Dean, W.B.; Wagner, D.R.; Afzal, V.; Lotz, J.C.; Rubin, E.M.; Bristow, J. Tenascin-X deficiency mimics Ehlers-Danlos syndrome in mice through alteration of collagen deposition. Nat. Genet. 2002, 30, 421-425. [CrossRef] [PubMed]

136. Margaron, Y.; Bostan, L.; Exposito, J.Y.; Malbouyres, M.; Trunfio-Sfarghiu, A.M.; Berthier, Y.; Lethias, C. Tenascin-X increases the stiffness of collagen gels without affecting fibrillogenesis. Biophys. Chem. 2010, 147, 87-91. [CrossRef] [PubMed]

137. Bellahcene, A.; Castronovo, V.; Ogbureke, K.U.; Fisher, L.W.; Fedarko, N.S. Small integrin-binding ligand N-linked glycoproteins (SIBLINGs): Multifunctional proteins in cancer. Nat. Rev. Cancer 2008, 8, 212-226. [CrossRef] 
138. Bouleftour, W.; Juignet, L.; Bouet, G.; Granito, R.N.; Vanden-Bossche, A.; Laroche, N.; Aubin, J.E.; Lafage-Proust, M.H.; Vico, L.; Malaval, L. The role of the SIBLING, Bone Sialoprotein in skeletal biology-Contribution of mouse experimental genetics. Matrix Biol. 2016, 52-54, 60-77. [CrossRef]

139. Icer, M.A.; Gezmen-Karadag, M. The multiple functions and mechanisms of osteopontin. Clin. Biochem. 2018, 59, 17-24. [CrossRef]

140. Coombes, J.D.; Swiderska-Syn, M.; Dollé, L.; Reid, D.; Eksteen, B.; Claridge, L.; Briones-Orta, M.A.; Shetty, S.; Oo, Y.H.; Riva, A.; et al. Osteopontin neutralisation abrogates the liver progenitor cell response and fibrogenesis in mice. Gut 2015, 64, 1120-1131. [CrossRef]

141. Zhao, H.; Wang, W.; Zhang, J.; Liang, T.; Fan, G.P.; Wang, Z.W.; Zhang, P.D.; Wang, X. Inhibition of osteopontin reduce the cardiac myofibrosis in dilated cardiomyopathy via focal adhesion kinase mediated signaling pathway. Am. J. Transl. Res. 2016, 8, 3645-3655. [PubMed]

142. Oh, K.; Seo, M.W.; Kim, Y.W.; Lee, D.S. Osteopontin Potentiates Pulmonary Inflammation and Fibrosis by Modulating IL-17/IFN-gamma-secreting T-cell Ratios in Bleomycin-treated Mice. Immune Netw. 2015, 15, 142-149. [CrossRef] [PubMed]

143. Wu, M.; Schneider, D.J.; Mayes, M.D.; Assassi, S.; Arnett, F.C.; Tan, F.K.; Blackburn, M.R.; Agarwal, S.K. Osteopontin in systemic sclerosis and its role in dermal fibrosis. J. Investig. Dermatol. 2012, 132, 1605-1614. [CrossRef] [PubMed]

144. Lorenzen, J.M.; Krämer, R.; Meier, M.; Werfel, T.; Wichmann, K.; Hoeper, M.M.; Riemekasten, G.; Becker, M.O.; Haller, H.; Witte, T. Osteopontin in the development of systemic sclerosis-Relation to disease activity and organ manifestation. Rheumatology 2010, 49, 1989-1991. [CrossRef]

145. Barizzone, N.; Marchini, M.; Cappiello, F.; Chiocchetti, A.; Orilieri, E.; Ferrante, D.; Corrado, L.; Mellone, S.; Scorza, R.; Dianzani, U.; et al. Association of osteopontin regulatory polymorphisms with systemic sclerosis. Hum. Immunol. 2011, 72, 930-934. [CrossRef] [PubMed]

146. Gheorghe, S.R.; Crăciun, A.M. Matrix Gla protein in tumoral pathology. Clujul. Med. 2016, 89, 319-321. [CrossRef] [PubMed]

147. Walker, J.T.; McLeod, K.; Kim, S.; Conway, S.J.; Hamilton, D.W. Periostin as a multifunctional modulator of the wound healing response. Cell Tissue Res. 2016, 365, 453-465. [CrossRef] [PubMed]

148. Murota, H.; Lingli, Y.; Katayama, I. Periostin in the pathogenesis of skin diseases. Cell Mol. Life Sci. 2017, 74, 4321-4328. [CrossRef]

149. Gerarduzzi, C.; Hartmann, U.; Leask, A.; Drobetsky, E. The Matrix Revolution: Matricellular Proteins and Restructuring of the Cancer Microenvironment. Cancer Res. 2020, 80, 2705-2717. [CrossRef]

150. Yamaguchi, Y.; Ono, J.; Masuoka, M.; Ohta, S.; Izuhara, K.; Ikezawa, Z.; Aihara, M.; Takahashi, K. Serum periostin levels are correlated with progressive skin sclerosis in patients with systemic sclerosis. Br. J. Dermatol. 2013, 168, 717-725. [CrossRef]

151. Kanaoka, M.; Yamaguchi, Y.; Komitsu, N.; Feghali-Bostwick, C.A.; Ogawa, M.; Arima, K.; Izuhara, K.; Aihara, M. Pro-fibrotic phenotype of human skin fibroblasts induced by periostin via modulating TGF- $\beta$ signaling. J. Dermatol. Sci. 2018, 90, 199-208. [CrossRef]

152. Yang, L.; Serada, S.; Fujimoto, M.; Terao, M.; Kotobuki, Y.; Kitaba, S.; Matsui, S.; Kudo, A.; Naka, T.; Murota, H.; et al. Periostin facilitates skin sclerosis via PI3K/Akt dependent mechanism in a mouse model of scleroderma. PLoS ONE 2012, 7, e41994. [CrossRef]

153. Kim, M.W.; Park, J.T.; Kim, J.H.; Koh, S.J.; Yoon, H.S.; Cho, S.; Park, H.S. Periostin in Mature Stage Localized Scleroderma. Ann. Dermatol. 2017, 29, 268-275. [CrossRef]

154. Bjørklund, G.; Svanberg, E.; Dadar, M.; Card, D.J.; Chirumbolo, S.; Harrington, D.J.; Aaseth, J. The Role of Matrix Gla Protein (MGP) in Vascular Calcification. Curr. Med. Chem. 2020, 27, 1647-1660. [CrossRef]

155. Proudfoot, D.; Shanahan, C.M. Molecular mechanisms mediating vascular calcification: Role of matrix Gla protein. Nephrology 2006, 11, 455-461. [CrossRef] [PubMed]

156. Malhotra, R.; Burke, M.F.; Martyn, T.; Shakartzi, H.R.; Thayer, T.E.; O’Rourke, C.; Li, P.; Derwall, M.; Spagnolli, E.; Kolodziej, S.A.; et al. Inhibition of bone morphogenetic protein signal transduction prevents the medial vascular calcification associated with matrix Gla protein deficiency. PLoS ONE 2015, 10, e0117098. [CrossRef]

157. Davies, C.A.; Jeziorska, M.; Freemont, A.J.; Herrick, A.L. Expression of osteonectin and matrix Gla protein in scleroderma patients with and without calcinosis. Rheumatology 2006, 45, 1349-1355. [CrossRef] [PubMed] 
158. Sawyer, A.J.; Kyriakides, T.R. Matricellular proteins in drug delivery: Therapeutic targets, active agents, and therapeutic localization. Adv. Drug Deliv. Rev. 2016, 97, 56-68. [CrossRef]

159. Ramaswamy, A.K.; Vorp, D.A.; Weinbaum, J.S. Functional Vascular Tissue Engineering Inspired by Matricellular Proteins. Front. Cardiovasc. Med. 2019, 6, 74. [CrossRef] [PubMed]

160. Morris, A.H.; Kyriakides, T.R. Matricellular proteins and biomaterials. Matrix Biol. 2014, 37, $183-191$. [CrossRef] [PubMed]

161. Makino, K.; Makino, T.; Stawski, L.; Lipson, K.E.; Leask, A.; Trojanowska, M. Anti-connective tissue growth factor (CTGF/CCN2) monoclonal antibody attenuates skin fibrosis in mice models of systemic sclerosis. Arthritis Res. Ther. 2017, 19, 134. [CrossRef]

162. Richeldi, L.; Pérez, E.R.F.; Costabel, U.; Albera, C.; Lederer, D.J.; Flaherty, K.R.; Ettinger, N.; Perez, R.; Scholand, M.B.; Goldin, J.; et al. Pamrevlumab, an anti-connective tissue growth factor therapy, for idiopathic pulmonary fibrosis (PRAISE): A phase 2, randomised, double-blind, placebo-controlled trial. Lancet Respir. Med. 2020, 8, 25-33. [CrossRef]

163. Haydont, V.; Bourgier, C.; Pocard, M.; Lusinchi, A.; Aigueperse, J.; Mathé, D.; Bourhis, J.; Vozenin-Brotons, M.C. Pravastatin Inhibits the Rho/CCN2/extracellular matrix cascade in human fibrosis explants and improves radiation-induced intestinal fibrosis in rats. Clin. Cancer Res. 2007, 13, 5331-5340. [CrossRef]

164. Bourgier, C.; Haydont, V.; Milliat, F.; François, A.; Holler, V.; Lasser, P.; Bourhis, J.; Mathé, D.; Vozenin-Brotons, M.C. Inhibition of Rho kinase modulates radiation induced fibrogenic phenotype in intestinal smooth muscle cells through alteration of the cytoskeleton and connective tissue growth factor expression. Gut 2005, 54, 336-343. [CrossRef]

165. Yamashita, T.; Asano, Y.; Taniguchi, T.; Nakamura, K.; Saigusa, R.; Miura, S.; Toyama, T.; Takahashi, T.; Ichimura, Y.; Yoshizaki, A.; et al. Glycyrrhizin Ameliorates Fibrosis, Vasculopathy, and Inflammation in Animal Models of Systemic Sclerosis. J. Investig. Dermatol. 2017, 137, 631-640. [CrossRef] [PubMed]

166. Colletti, M.; Galardi, A.; De Santis, M.; Guidelli, G.M.; Di Giannatale, A.; Di Luigi, L.; Antinozzi, C. Exosomes in Systemic Sclerosis: Messengers Between Immune, Vascular and Fibrotic Components? Int. J. Mol. Sci. 2019, 20, 4337. [CrossRef] [PubMed]

167. Chen, L.; Brenner, D.A.; Kisseleva, T. Thrombospondin 1 is a key mediator of transforming growth fact. Hepatol. Commun. 2019, 3, 180-192. [PubMed]

168. Wermuth, P.J.; Piera-Velazquez, S.; Jimenez, S.A. Exosomes isolated from serum of systemic sclerosis patients display alterations in their content of profibrotic and antifibrotic microRNA and induce a profibrotic phenotype in cultured normal dermal fibroblasts. Clin. Exp. Rheumatol. 2017, 35, 21-30. [PubMed]

169. Chouri, E.; Servaas, N.H.; Bekker, C.P.J.; Affandi, A.J.; Cossu, M.; Hillen, M.R.; Angiolilli, C.; Mertens, J.S.; Van den Hoogen, L.L.; Silva-Cardoso, S.; et al. Serum microRNA screening and functional studies reveal miR-483-5p as a potential driver of fibrosis in systemic sclerosis. J. Autoimmun. 2018, 89, 162-170. [CrossRef]

170. Yanaba, K. Strategy for treatment of fibrosis in systemic sclerosis: Present and future. J. Dermatol. 2016, 43, 46-55. [CrossRef] [PubMed]

171. Prakoura, N.; Chatziantoniou, C. Matricellular Proteins and Organ. Fibrosis. In Current Pathobiology Reports; Springer: New York, NY, USA, 2017; pp. 111-121.

(C) 2020 by the authors. Licensee MDPI, Basel, Switzerland. This article is an open access article distributed under the terms and conditions of the Creative Commons Attribution (CC BY) license (http://creativecommons.org/licenses/by/4.0/). 